\title{
Perbedaan Gender pada Kejadian Sindrom Metabolik pada Penduduk Perkotaan di Indonesia
}

\author{
Gender Difference in the Occurrence of Metabolic Syndrome in Indonesian \\ Urban Population
}

\author{
Krisnawaty Bantas *, Hari Koesnanto Yosef**, Budi Moelyono**
}

\begin{abstract}
*Departemen Epidemiologi Fakultas Kesehatan Masyarakat Universitas Indonesia, **Program Studi Ilmu Kesehatan dan Kedokteran Kesehatan Universitas Gadjah Mada
\end{abstract}

\begin{abstract}
Abstrak
Sindrom Metabolik (SM) merupakan faktor risiko penting penyakit kardiovaskuler yang merupakan penyebab utama kematian di Indonesia. Perbedaan gender pada SM berkontribusi terhadap perbedaan gender pada penyakit kardiovaskuler. Penelitian ini bertujuan mengetahui prevalensi dan risiko SM berdasarkan gender di perkotaan Indonesia menggunakan data Riset Kesehatan Dasar 2007 dan menggunakan rancangan penelitian potong lintang. Populasi penelitian terdiri dari 13.262 orang pria dan wanita yang tidak hamil berusia lebih dari 15 tahun yang bermukim di daerah perkotaan. Variabel penelitian meliputi variabel dependen sindrom metabolik. Variabel independen utama adalah gender dan variabel kovariat yang lain adalah level 1 (umur, status perkawinan, pendidikan, stres, merokok, dan aktivitas fisik), level 2 (pendapatan keluarga, konsumsi energi rumah tangga, konsumsi protein rumah tangga, konsumsi serat rumah tangga, anggota rumah tangga, dan balita dalam rumah tangga), dan level 3 (provinsi, status urban, dan Indeks Pembangunan Manusia (IPM)). Analisis dilakukan dengan multilevel regresi logistik. Hasil penelitian menyebutkan bahwa prevalensi SM adalah $17,5 \%$, prevalensi pada wanita $(21,3 \%)$ lebih tinggi daripada pria (12,9\%). Risiko sindrom metabolik berdasarkan gender bergantung pada status umur, pendidikan, dan perkawinan dari individu. Variasi kejadian SM berdasarkan pendapatan keluarga kecil (nilai MOR 1,21) dan variasi kejadian SM berdasarkan provinsi juga kecil (nilai MOR 1,18).

Kata kunci: analisis multilevel, gender, sindrom metabolik
\end{abstract}

Abstract

Metabolic Syndrome (MS) is an important factor for Cardiovascular Disease (CVD). One of the main causes of death in Indonesia is CVD. Gender differences in MS may contribute the gender differences in CVD. This study aimed to examine the prevalence and MS risk by gender in the urban population of Indonesia using Riskesdas 2007 data and cross-sectional design study. Population of study consisted of 13,262 men and non pregnant women over 15 years old lived in urban area. Variables included in this study are MS as the de- pendent variable and gender as the main independent variable. The covariate variables consisted of: level 1 variables (age, marital status, education, stress, smoking, and physical activity), level 2 (family outcome, household energy consumption, protein consumption, fiber consumption, members, and toddler under 5 years), level 3 (province, urban status, and human development index). Multilevel logistic regression used in data analysis. Result showed that prevalence of MS was $17,5 \%$, on women (21.3\%) was higher than men (12.9\%). The risk of MS by gender was depent on age, educational level, and marital status of individual. The variation of MS occurrence among the family incomes was small (MOR 1.21), and the variation of MS occurrence among the provinces was also small (MOR 1.18).

Keywords: multilevel analysis, gender, metabolic syndrome

\section{Pendahuluan}

Pada akhir abad ke-20, penyakit kardiovaskuler menjadi penyebab utama morbiditas dan mortalitas di berbagai negara, terutama di negara-negara maju. Pada tahun 1990, di berbagai negara berkembang, kematian akibat penyakit tidak menular terhitung sebanyak 68\% dari seluruh kematian dan sekitar 63\% disebabkan oleh penyakit kardiovaskuler. ${ }^{1}$ Di Indonesia, dengan jumlah absolut penduduk usia lanjut yang meningkat, diperkirakan berbagai penyakit degeneratif seperti kardiovaskuler, neoplasma, diabetes melitus dan penyakit tulang dan sendi mengalami peningkatan. Dari Survei Kesehatan Rumah Tangga, penyakit kardiovaskuler merupakan penyebab utama kematian, meningkat dari urutan 11 pada tahun 1972, menjadi urutan 3 pada tahun 1986, dan menjadi urutan pertama pada tahun $1992 .^{2}$

Alamat Korespondensi: Krisnawaty Bantas, Departemen Epidemiologi Fakultas Kesehatan Masyarakat Gd. A Lt. 1, Kampus Baru UI Depok 16424, Hp.021-78849031,e-mail: krisnabantas@yahoo.com 
Sindrom Metabolik (SM) merupakan faktor risiko penting diabetes melitus tipe 2 dan penyakit kardiovaskuler. ${ }^{3}$ Perbedaan gender pada SM berkontribusi pada penyakit kardiovaskuler dan diabetes melitus tipe 2. Prevalensi SM pada komunitas Barat dan Asia memperlihatkan trend yang meningkat. Di AS, prevalensi SM lebih tinggi pada wanita dan meningkat secara tajam. ${ }^{4}$ Di Eropa, prevalensi SM pada pria lebih tinggi daripada wanita. ${ }^{5}$

Di Indonesia, belum pernah dipublikasikan penelitian tentang prevalensi SM dalam skala besar. Penelitian di berbagai negara Barat menunjukkan miskonsep tentang penyakit kardiovaskuler. Para wanita kurang waspada terhadap penyakit tersebut dibanding pria, terdapat anggapan bahwa penyakit kardiovaskuler adalah penyakit para pria. ${ }^{6}$ Sementara itu, fakta epidemiologis menunjukkan peningkatan insiden penyakit jantung koroner pada wanita. Selain itu, para dokter lebih lambat memulai terapi preventif, lebih sedikit menginvestigasi faktorfaktor risiko penyakit kardiovaskuler, mendiagnosis, merujuk para spesialis, dan memberikan perawatan untuk kondisi Infark Miokard (IM) pada wanita. ${ }^{7}$ Walaupun para wanita lebih lambat 10 tahun mengalami manifestasi pertama penyakit kardiovaskuler daripada pria, tetapi wanita berisiko lebih besar meninggal setelah serangan IM. ${ }^{8}$ Masyarakat dan kampanye media menyebabkan wanita lebih terfokus pada penyakit kanker payudara, walaupun angka kematian kardiovaskuler lebih besar daripada kanker payudara. ${ }^{9}$

Ketidaksetaraan gender pada suatu status kesehatan merefleksikan ketidaksamaan faktor biologis yang terkait seks dan faktor sosial serta interaksi kedua faktor tersebut. ${ }^{10}$ Secara biologis, masih terdapat perbedaan pendapat tentang peran hormon androgen dalam mediasi penyakit kardiovaskuler. Sementara, hormon estrogen dianggap dapat memproteksi kejadian penyakit kardiovaskuler. Perbedaan faktor risiko penyakit kardiovaskuler pada wanita dan pria berhubungan dengan interaksi berbagai faktor risiko dengan hormon wanita/pria, dan berperan penting dalam perkembangan SM dan penyakit kardiovaskuler berdasarkan gender. ${ }^{11}$ Penelitian tentang SM sebagai indikator penyakit kardiovaskuler menjadi penting karena SM mewakili faktor risiko utama penyakit kardiovaskuler pada gender. Selain itu, perbedaan gender pada SM dapat berkontribusi pada perbedaan penyakit kardiovaskuler. Penelitian ini bertujuan mengetahui prevalensi dan risiko SM berdasarkan gender di populasi perkotaan Indonesia. Jenis kelamin tidak dapat dimodifikasi, tetapi penelitian ketidaksetaraan gender pada kejadian SM penting karena berguna untuk bahan perencanaan dalam program kontrol penyakit kardiovaskuler berbasis gender.

\section{Metode}

Penelitian yang menggunakan data sekunder Riset Kesehatan Dasar tahun 2007 ini dilakukan di 33 provinsi,
438 kabupaten/kota di Indonesia menggunakan rancangan penelitian potong lintang. Populasi penelitian terdiri dari 13.262 orang pria dan wanita yang tidak hamil berusia lebih dari 15 tahun, yang bermukim di wilayah perkotaan di seluruh provinsi di Indonesia. Variabel penelitian meliputi SM sebagai variabel dependen dan sebagai variabel independen gender. Variabel kovariat level individu meliputi umur, status perkawinan, pendidikan, status stres, merokok, dan aktivitas fisik. Variabel klaster level 2 terdiri dari pendapatan keluarga, konsumsi energi rumah tangga, konsumsi protein rumah tangga, porsi konsumsi serat rumah tangga, jumlah anggota rumah tangga, dan balita dalam rumah tangga. Variabel klaster level 3 adalah provinsi, status urban, dan status Indeks Pembangunan Manusia (IPM).

SM adalah kondisi responden yang minimal memenuhi tiga kriteria meliputi peningkatan ukuran lingkar perut (pria $\geq 85 \mathrm{~cm}$, wanita $\geq 83,5 \mathrm{~cm}$ ), hipertensi, hiperglikemia, dan/atau kadar HDL (pria $\leq 40 \mathrm{mg} / \mathrm{dl}$, wanita $\leq 50 \mathrm{mg} / \mathrm{dl}$ ). Hipertensi adalah kondisi meminum obat anti hipertensi atau pengukuran tekanan darah lebih dari 130/85 mmHg. ${ }^{12}$ Hiperglikemia ditentukan berdasarkan kadar gula darah postprandial di atas $140 \mathrm{mg} / \mathrm{dl}$, didiagnosa DM, penderita DM atau meminum obat DM. Penurunan kadar HDL pada laki-laki $\leq 40 \mathrm{mg} / \mathrm{dl}$ dan perempuan $\leq 50 \mathrm{mg} / \mathrm{dl} .{ }^{12}$ Obesitas diukur secara antropometri berdasarkan perbandingan berat badan $(\mathrm{kg})$ dan tinggi badan $\left(\mathrm{m}^{2}\right) .{ }^{12}$ Pengukuran kadar gula darah postprandial, kadar kolesterol HDL, dilakukan di 33 provinsi terdiri dari 438 kabupaten/kota di Indonesia dengan populasi penduduk urban di Indonesia.

\section{Hasil}

Total sampel penelitian adalah 13.262 orang, terdiri dari 6.026 pria dan 7.236 wanita yang tidak hamil, berusia lebih dari 15 tahun, tinggal di daerah perkotaan seluruh provinsi di Indonesia.

\section{Prevalensi Sindrom Metabolik}

Prevalensi SM total adalah 17,5\%. Prevalensi SM pada wanita $(21,3 \%)$ lebih tinggi daripada pria $(12,9 \%)$. Prevalensi masing-masing komponen SM adalah sebagai berikut: prevalensi hipertensi secara keseluruhan adalah $54,7 \%$, prevalensi pada wanita $(52,8 \%)$ lebih rendah daripada pria $(56,9 \%)$, prevalensi hiperglikemia 2 jam PP secara keseluruhan adalah $15,4 \%$, lebih tinggi pada wanita $(17,6 \%)$ daripada pria $(12,8 \%)$, prevalensi hipokolesterolemia secara keseluruhan adalah $53,7 \%$, pada wanita $(61,3 \%)$ lebih tinggi daripada pria $(44,6 \%)$ dan prevalensi obesitas sentralis secara keseluruhan adalah $26,4 \%$, pada wanita $(31,6 \%)$ lebih tinggi daripada pria $(20,2 \%)$ (Tabel 1). Terdapat 3 dari 4 komponen SM yaitu hiperglikemia 2 jam PP, hipokolesterolemia HDL, dan obesitas sentralis yang prevalensinya lebih tinggi pada wanita daripada pria. Kondisi tersebut memberikan kontribusi terhadap lebih tingginya prevalensi SM pada wanita dibanding pria. 


\section{Risiko Sindrom Metabolik Berdasarkan Gender}

Untuk mengukur risiko SM berdasarkan gender, dikembangkan 4 model. Model 0-1 merupakan model dengan variabel independen utama gender dan SM. Model 0-2 merupakan model dengan variabel independen utama bersama variabel klaster level 2 dan variabel klaster level 3. Pada model 1, semua variabel eksplanatoris level 1 dimasukkan bersama dengan 'random effect' level 2 (pendapatan rumah tangga) dan level 3 (provinsi), Model 2 merupakan pengembangan dari model 1 yang memasukkan kovariat dari variabel klaster level 2 (energi, protein, serat, anggota rumah tangga, dan balita dalam rumah tangga). Model 3 merupakan pengembangan dari model 2 yang memasukkan kovariat dari variabel klaster level 3 (status urban, IPM). Model 4, pengembangan dari model 3 dengan mengeluarkan variabel kovariat yang tidak berhubungan secara signifikan dengan SM.

Pada model 0-1, sebelum dikontrol dengan variabel kovariat level 1,level 2, dan level 3 terlihat hubungan secara statistik yang bermakna antara gender dan SM. Wanita berisiko SM 1,82 kali lebih tinggi dibanding pria. Pada model 0-2, setelah dikontrol variabel klaster level 2 (pendapatan keluarga) dan variabel klaster level 3 (provinsi), terjadi perubahan nilai Odds Ratio (OR) menjadi 1,28 dengan nilai $\mathrm{p} 0,000$. Hal ini memperlihatkan hubungan yang bermakna antara gender dan SM. Wanita berisiko mengalami SM 1,28 kali lebih besar daripada pria. Nilai Median Odds Ratio (MOR) pada level 3 dan level 2 adalah 1,23 dan 1,15 menunjukkan heterogenitas yang kecil untuk kejadian SM pada level 3 dan level 2 (Tabel 2).

Perubahan nilai OR untuk variabel gender terhadap kejadian SM pada model 1, model 2, model 3, dan model 4, yaitu nilai OR 1,32 pada model 1 berubah menjadi 1,28 pada model 2, dan 1,29 pada model 3. Setelah beberapa variabel kovariat yang tidak berhubungan bermakna secara statistik dikeluarkan dari model, terlihat nilai OR berubah kembali menjadi 1,32. Apabila dibandingkan dengan model 0-1, nilai OR $=1,82$ (Tabel $3)$, setelah dikontrol dengan variabel "random-effect" level 2 dan level 3 beserta variabel kovariat level 1, level 2, dan level 3 yang berhubungan dengan kejadian SM, terlihat perubahan nilai OR dari 1,82 menjadi 1,32 yang menunjukkan OR kejadian SM antara individu wanita dan pria adalah 1,32 . Nilai $p<0,05$ menunjukkan ada hubungan bermakna secara statistik antara gender dan kejadian SM. Wanita berisiko mengalami SM 1,32 kali lebih besar daripada pria.

Setelah variabel kovariat yang tidak berhubungan bermakna dengan SM dikeluarkan dari model, untuk variabel klaster level 2, pada model 4 nilai MOR menjadi 1,21. Hal ini menunjukkan bahwa heterogenitas dari klaster level 2 kecil. Artinya, variasi kejadian SM di antara klaster level
Tabel 1. Distribusi Responden Berdasarkan Status Sindrom Metabolik, Tekanan Darah, Hiperglikemia 2 Jam PP, dan Kadar Kolesterol HDL dan IMT

\begin{tabular}{lccc}
\hline Variabel & $\begin{array}{c}\text { Seluruh } \\
\text { Responden }\end{array}$ & $\begin{array}{c}\text { Responden } \\
\text { Wanita }\end{array}$ & $\begin{array}{c}\text { Responden } \\
\text { Pria }\end{array}$ \\
\hline Sindrom Metabolik & $17,5 \%$ & $21,3 \%$ & $12,9 \%$ \\
Hipertensi & $54,7 \%$ & $52,8 \%$ & $56,9 \%$ \\
Hiperglikemia 2 jam PP & $15,4 \%$ & $17,6 \%$ & $12,8 \%$ \\
Hipokolesterolemia -HDL & $53,7 \%$ & $61,3 \%$ & $44,6 \%$ \\
Obesitas sentralis & $26,4 \%$ & $31,6 \%$ & $20,2 \%$ \\
\hline
\end{tabular}

Tabel 2. Perubahan Nilai OR Kejadian Sindrom Metabolik Variabel Gender pada Model 0-1 dan Model 0-2

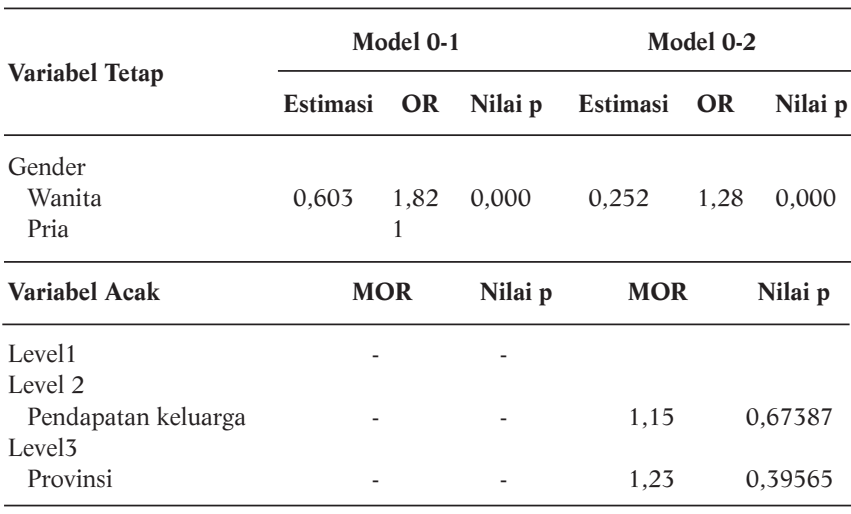

2 (pendapatan keluarga) kecil. Pada variabel klaster level3 (provinsi), nilai MOR pada model 4 menjadi 1,18, menunjukkan bahwa heterogenitas pada variabel klaster level 3 (provinsi) terhadap kejadian SM kecil, berarti variasi kejadian SM di antara klaster level 3 (provinsi) kecil (Tabel 4).

\section{Uji Interaksi}

Pada uji interaksi, terdapat 3 variabel yang memberi hasil uji interaksi yang bermakna secara statistik. Variabel tersebut adalah interaksi antara variabel umur*gender, status perkawinan*gender, dan variabel rokok"gender.

\section{Risiko Sindrom Metabolik Berdasarkan Gender dan Umur}

Hasil analisis multivariat multilevel dalam penelitian menunjukkan bahwa terdapat interaksi antara variabel gender dan umur terhadap kejadian SM.

Berdasarkan umur, wanita pada usia di atas 60 tahun memiliki risiko untuk terkena SM 1,17 kali lebih tinggi daripada pria, wanita usia 50 - 59 berisiko menderita SM 1,67 kali lebih tinggi daripada pria, wanita usia $40-49$ tahun berisiko SM 1,33 kali lebih tinggi daripada pria, pada wanita usia 30 - 39 tahun berisiko SM 1,33 kali lebih tinggi daripada pria, dan wanita usia $<30$ tahun berisiko SM 1,07 kali lebih tinggi daripada pria.

Risiko SM pada wanita berdasarkan umur, jika dibandingkan wanita berusia $<30$ tahun, wanita berumur $>60$ 
Tabel 3. Model Logistik Regresi Multilevel Multivariat Model 1, Model 2, Model 3, dan Model 4, Perubahan Nilai OR dan MOR

\begin{tabular}{|c|c|c|c|c|}
\hline \multirow{2}{*}{ Variabel Tetap } & \multicolumn{4}{|c|}{ OR } \\
\hline & Model 1 & Model 2 & Model 3 & Model 4 \\
\hline \multicolumn{5}{|l|}{ Status gender } \\
\hline Wanita & $1,32 *$ & $1,28 *$ & $1,29 *$ & $1,32 *$ \\
\hline Pria & 1 & 1 & 1 & 1 \\
\hline \multicolumn{5}{|l|}{ Umur (tahun) } \\
\hline$>60$ & $2,82 *$ & $2,83^{*}$ & $2,84^{*}$ & $2,87 *$ \\
\hline $50-59$ & $1,78^{*}$ & $1,78^{*}$ & $1,78^{*}$ & $1,78^{*}$ \\
\hline $40-49$ & $1,41^{*}$ & $1,41^{*}$ & $1,40 *$ & $1,39 *$ \\
\hline $30-39$ & $1,26^{*}$ & $1,26^{*}$ & $1,26^{*}$ & $1,26^{*}$ \\
\hline$<30$ & 1 & 1 & 1 & 1 \\
\hline \multicolumn{5}{|l|}{ Merokok } \\
\hline Berat & $0,79 *$ & $0,78^{*}$ & $0,80 *$ & $0,80^{*}$ \\
\hline Sedang & $1,17 *$ & $1,17^{*}$ & $1,18^{*}$ & $1,18^{*}$ \\
\hline Ringan & $1,33 *$ & $1,32 *$ & $1,33^{*}$ & $1,32^{*}$ \\
\hline Tidak merokok & 1 & 1 & 1 & 1 \\
\hline \multicolumn{5}{|l|}{ Status Perkawinan } \\
\hline Janda/duda & $2,24 *$ & $2,23 *$ & $2,30 *$ & $2,22 *$ \\
\hline Kawin & $0,90^{*}$ & $0,88^{*}$ & $0,81 *$ & $0,88^{*}$ \\
\hline Tidak kawin & 1 & 1 & 1 & 1 \\
\hline \multicolumn{5}{|l|}{ Tingkat Pendidikan } \\
\hline$>$ SLTA & $0,90^{*}$ & 0,90 & 1,06 & 0,90 \\
\hline SLTA & $1,11^{*}$ & $1,11^{*}$ & 1,10 & $1,11^{*}$ \\
\hline$<$ SLTA & 1 & 1 & 1 & 1 \\
\hline \multicolumn{5}{|l|}{ Status stres } \\
\hline Ya & 1,08 & 1,08 & $1,10^{*}$ & $1,08^{*}$ \\
\hline Tidak & 1 & 1 & 1 & 1 \\
\hline \multicolumn{5}{|l|}{ Aktivitas Fisik } \\
\hline Kwt 1 (0-240 mnt/mg) & $1,15^{*}$ & $1,16^{*}$ & $1,17^{*}$ & $1,16^{*}$ \\
\hline Kwt 2 (241-40 mnt/mg) & 1,02 & 0,97 & 0,99 & 0,98 \\
\hline Kwt 3 (841-1680 mnt/mg) & 0,94 & 0,95 & 0,94 & 0,95 \\
\hline Kwt 4 (>1680 mnt/mg) & 1 & 1 & 1 & 1 \\
\hline
\end{tabular}

\begin{tabular}{|c|c|c|c|c|}
\hline \multicolumn{5}{|l|}{ Level-2 covariates } \\
\hline \multicolumn{5}{|l|}{ Anggota Keluarga } \\
\hline Kwt 4 (>6 orang) & - & 0,84 & 0,85 & $0,84 *$ \\
\hline Kwt 3 (5-6 orang) & - & 1,00 & 1,01 & 1,01 \\
\hline Kwt 2 (3-4 orang) & - & 1,05 & 1,04 & 1,04 \\
\hline Kwt 1 (<3 orang) & - & 1 & 1 & 1 \\
\hline \multicolumn{5}{|l|}{ Balita dalam RT } \\
\hline $\mathrm{Ya}$ & - & $0,89 *$ & $0,89 *$ & $0,89 *$ \\
\hline Tidak & 1 & 1 & & \\
\hline \multicolumn{5}{|l|}{ Level -3 covariates } \\
\hline \multicolumn{5}{|l|}{ Status urban } \\
\hline Kota & - & - & 1,10 & 1,08 \\
\hline Kabupaten & 1 & & & \\
\hline \multirow{2}{*}{ Variabel Acak } & \multicolumn{4}{|c|}{ MOR } \\
\hline & Model 1 & Model 2 & Model 3 & Model 4 \\
\hline Level1 & - & - & - & - \\
\hline Level 2 & & & & \\
\hline $\begin{array}{l}\text { Pendapatan keluarga } \\
\text { Level3 }\end{array}$ & 1,15 & 1,27 & 1,28 & 1,21 \\
\hline Provinsi & 1,18 & 1,67 & 1,73 & 1,18 \\
\hline
\end{tabular}

*nilai $\mathrm{p}<0,05$

Risiko SM pada pria berdasarkan umur, jika dibandingkan pria usia $<30$ tahun, pria berumur $>60$ tahun berisiko 2,26 kali lebih tinggi, pria berumur $50-59$
Tabel 4. Hasil Uji Interaksi antara Variabel Gender dengan Variabel-Variabel Kovariat dalam Hubungannya dengan Kejadian Sindrom Metabolik

\begin{tabular}{lllll}
\hline & \multicolumn{3}{c}{ Model Akhir } \\
\cline { 2 - 5 } Variabel Tetap & Estimasi & SE & OR & Nilai p \\
\cline { 2 - 5 } & & & & \\
\hline Gender*Umur & & & \\
Gender*Umur (>60 tahun) & 0,5350 & 0,0950 & 1,71 & 0,000 \\
Gender*Umur (50-59 tahun) & 0,5111 & 0,1112 & 1,67 & 0,000 \\
Gender*Umur(40-49 tahun) & 0,2857 & 0,0622 & 1,33 & 0,000 \\
Gender*Umur(30-39 tahun) & 0,2855 & 0,0527 & 1,33 & 0,000 \\
Gender*Umur (<30 tahun) & 0,0748 & 0,0365 & 1,07 & 0,000 \\
Gender*Status Perkawinan & & & & \\
Gender*Cerai & 0,5240 & 0,1278 & 1,69 & 0,000 \\
Gender*Kawin & 0,2490 & 0,0394 & 1,28 & 0,000 \\
Gender*Tidak kawin & 0,0554 & 0,0560 & 1,05 & 0,323 \\
Gender*Pendidikan & & & & \\
Gender*> SLTA & $-0,1771$ & 0,0898 & 0,84 & 0,049 \\
Gender*SLTA & 0,0342 & 0,0450 & 1,03 & 0,448 \\
Gender*< SLTA & 0,3973 & 0,0350 & 1,49 & 0,000 \\
\hline
\end{tabular}

berisiko 1,56 kali lebih tinggi, pria berumur $40-49$ tahun berisiko 1,38 lebih tinggi, pria berumur $30-39$ tahun berisiko 1,32 kali lebih tinggi (Tabel 5).

\section{Risiko Sindrom Metabolik Berdasarkan Gender dan Status Pendidikan}

Hasil analisis multivariat multilevel dalam penelitian menunjukkan bahwa terdapat interaksi antara variabel gender dan pendidikan terhadap kejadian SM.

Risiko SM pada wanita dibandingkan pria berdasarkan pendidikan, pada strata pendidikan > SLTA, 0,84 kali lebih tinggi dibanding pria pada strata pendidikan yang sama (nilai $p=0,0485$ ). Pada strata pendidikan SLTA tidak ada perbedaan risiko mempunyai SM pada wanita dan pria $(\mathrm{OR}=1,03$; nilai $\mathrm{p}=0,4478)$. Pada strata pendidikan $<$ SLTA wanita memiliki risiko SM 1,49 lebih tinggi dibanding pria (nilai $p=0,000$ ). Atau dengan kata lain pria dengan pendidikan yang rendah dari SMA memiliki risiko SM 1,19 kali lebih besar dibanding wanita dengan pendidikan yang sama (Tabel 4).

Risiko SM pada wanita berdasarkan status pendidikan, wanita dengan strata pendidikan > SLTA memiliki risiko SM lebih rendah dibanding wanita dengan strata pendidikan $<$ SLTA $(O R=0,70$; nilai $\mathrm{p}=0,0065)$. Wanita dengan strata pendidikan SMA memiliki risiko yang tidak berbeda dengan wanita dengan strata pendidikan $<$ SLTA $(O R=1,05$; nilai $p=0,6084)$.

Risiko SM pada pria berdasarkan pendidikan, pria dengan strata pendidikan >SLTA memiliki risiko yang tidak berbeda dengan pria dengan strata pendidikan < SLTA $(O R=1,14$; nilai $\mathrm{p}=0,4393)$. Pria dengan strata pendidikan SMA memiliki risiko yang tidak berbeda dengan pria dengan strata pendidikan $<$ SMA $(\mathrm{OR}=$ $1,12$; nilai $\mathrm{p}=0,3645)($ Tabel 5$)$. 
Tabel 5. Persamaan Regresi pada Analisis Subpopulasi Gender untuk Variabel Interaksi Umur, Status Perkawinan dan Pendidikan untuk Hubungan antara Gender dengan Sindrom Metabolik

\begin{tabular}{|c|c|c|c|c|c|c|c|c|}
\hline \multirow{3}{*}{ Variabel Tetap } & \multicolumn{8}{|c|}{ Model Akhir } \\
\hline & \multicolumn{4}{|c|}{ Subpopulasi Wanita } & \multicolumn{4}{|c|}{ Subpopulasi Pria } \\
\hline & Estimasi & SE & OR & Nilai $p$ & Estimasi & SE & OR & Nilai $p$ \\
\hline \multicolumn{9}{|l|}{ Umur } \\
\hline Umur (>60 tahun) & 1.2766 & 0.0648 & 3.58 & 0.0000 & 0.8158 & 0.0607 & 2.26 & 0.0000 \\
\hline Umur (50-59 tahun) & 0.7687 & 0.0872 & 2.17 & 0.0000 & 0.4574 & 0.0797 & 1.56 & 0.0000 \\
\hline Umur (40-49 tahun) & 0.4152 & 0.0697 & 1.42 & 0.0000 & 0.3215 & 0.0670 & 1.38 & 0.0000 \\
\hline Umur (30-39 tahun) & 0.1565 & 0.0725 & 1.18 & 0.0309 & 0.2720 & 0.0707 & 1.32 & 0.0001 \\
\hline Umur $(<30$ tahun $)$ & & & 1 & & & & 1 & \\
\hline \multicolumn{9}{|l|}{ Status Perkawinan } \\
\hline Cerai & 0.9283 & 0.0884 & 2.53 & 0.0000 & 0.5265 & 0.1089 & 1.69 & 0.0000 \\
\hline Kawin & -0.2093 & 0.0740 & 0.81 & 0.0046 & -0.2940 & 0.1034 & 0.74 & 0.0045 \\
\hline Tidak kawin & & & 1 & & & & 1 & \\
\hline \multicolumn{9}{|l|}{ Pendidikan } \\
\hline$>$ SLTA & -0.3563 & 0.1309 & 0.70 & 0.0065 & 0.13345 & 0.1725 & 1.14 & 0.4393 \\
\hline$=$ SLTA & 0.0475 & 0.0927 & 1.05 & 0.6084 & 0.11316 & 0.9067 & 1.12 & 0.3645 \\
\hline$<$ SLTA & & & 1 & & & & 1 & \\
\hline
\end{tabular}

\section{Risiko SM Berdasarkan Gender dan Status Perkawinan}

Hasil analisis multivariat menunjukkan bahwa terdapat interaksi antara variabel gender dan status perkawinan untuk kejadian SM. Pada status janda, wanita janda berisiko mempunyai SM 1,69 kali lebih tinggi dibanding pria dengan status duda $(\mathrm{OR}=1,69$; nilai $\mathrm{p}=0,000)$. Pada status kawin, wanita berisiko mempunyai SM 1,28 kali dibanding pria dengan status yang sama $(\mathrm{OR}=1,28$; nilai $\mathrm{p}=0,000$ ). Pada status belum kawin, wanita mempunyai risiko yang tidak berbeda dengan pria dengan status yang sama $(O R=1,05$; nilai $p=0,32283)$ (Tabel 4).

Risiko SM pada wanita berdasarkan status perkawinan, kejadian SM pada strata janda 2,53 kali dibanding strata yang belum menikah $(\mathrm{OR}=2,53$; nilai $\mathrm{p}=0,000$ ), pada strata kawin, kejadian SM pada wanita kawin 0,81 kali dibandingkan wanita yang belum kawin $(\mathrm{OR}=0,81$; nilai $\mathrm{p}=0,0045)$.

Risiko SM pada pria berdasarkan status perkawinan: kejadian SM pada strata duda 1,69 kali dibanding strata yang belum menikah $(\mathrm{OR}=1,69$; nilai $\mathrm{p}=0,000)$, pada strata kawin, kejadian SM pada pria kawin 0,76 kali dibandingkan pria yang belum kawin $(\mathrm{OR}=0,76$; nilai $\mathrm{p}$ $=0,0045)($ Tabel 5).

\section{Pembahasan}

Dalam penelitian ini prevalensi SM adalah 17,5\% (Tabel 1). Prevalensi SM di Amerika Serikat sekitar 25\% dari populasi. Di AS kenaikan prevalensi SM yang tajam terjadi pada wanita karena kenaikan obesitas yang konsisten pada wanita dan jumlah wanita lebih banyak daripada pria di AS. ${ }^{13}$ Prevalens SM telah dilaporkan dari Negara-negara Afrika-sub Sahara dan Timur Tengah, Afrika Selatan, Maroko, Oman, Turki dan Iran, berkisar antara $16-33,7 \%$.
Demikian pula di Venezuela $31,2 \%$ dan Brazil 25,4\%. ${ }^{14}$ Di kawasan Asia, prevalensi SM di India sebanyak 28,8\%, Melayu 24,2\%, dan Cina 14,8\%. Di Korea, penelitian menunjukkan bahwa prevalens SM di populasi adalah 29\%. ${ }^{15}$ Apabila dibandingkan dengan negara-negara tersebut, prevalensi SM dalam penelitian ini masih di bawah AS, rata-rata negara Afrika-sub Sahara, Venezuela, Brazil, India, dan Malaysia. Akan tetapi, bila dibandingkan Cina, prevalensi SM dalam penelitian ini sedikit lebih tinggi.

Berdasakan gender, prevalensi SM pada penelitian ini lebih tinggi pada wanita $(21,3 \%)$ dibanding pria $(12,9 \%)$. Kondisi ini sesuai dengan temuan dari hasil penelitian di beberapa negara. Selama dekade terakhir ini prevalens sindrom metabolik meningkat, tapi tampak lebih tajam pada wanita dari pada pria. Penelitian pada orang dewasa Portugis menunjukkan bahwa SM lebih tinggi pada wanita $(24,9 \%)$ daripada pria $(17,4 \%)$ dan di Spanyol, prevalensi SM lebih menonjol pada wanita $(30,9 \%)$ dibanding pria $(27,1 \%) .16$ Namun, di beberapa negara prevalensi SM justru lebih tinggi pada pria dibanding wanita.

Di beberapa negara, prevalensi SM lebih tinggi pada pria dibanding wanita. Penelitian di Prancis menemukan bahwa SM lebih sering terjadi pada pria (23\%) daripada wanita $(16,9 \%)$. Di Hongaria, prevalensi umum SM adalah $11,5 \%$ (14,9\% pada pria dan $8,6 \%$ pada wanita). ${ }^{17}$ Hal yang sama juga terlihat pada penelitian di Korea Selatan yang menemukan prevalensi SM pada pria $29,0 \%$ dan $16,8 \%$ pada wanita. ${ }^{15}$ Di Taiwan, hasil penelitian menunjukkan bahwa SM lebih prevalensi pada pria $(20,4 \%)$ lebih tinggi daripada wanita $(15,3 \%) .{ }^{16}$ 


\section{Risiko SM Berdasarkan Gender dan Umur}

Hasil analisis multivariat multilevel dalam penelitian menunjukkan bahwa pada semua strata umur, wanita berisiko lebih tinggi untuk terkena SM dibanding pria. Di samping itu, dengan bertambahnya umur, terjadi peningkatan yang linier terhadap risiko SM pada wanita dibanding pria. Risiko SM pada wanita makin meningkat secara drastis dibanding pria setelah usia 50 tahun ke atas $(\mathrm{OR}=1,67$ pada usia $50-59$ dan $\mathrm{OR}=1,71$ pada usia $>60$ tahun)

Peningkatan insidens SM selama periode postmenopause telah ditunjukkan oleh banyak penelitian di seluruh dunia. Terdapat peningkatan $60 \%$ risiko SM dan peningkatan insidens SM pada postmenopause setelah dikontrol dengan berbagai faktor latar belakang. ${ }^{18}$ Perbedaan status metabolik dari tubuh dan tipe substitusi lemak pada jaringan yang berbeda merupakan salah satu teori tentang meningkatnya insidens SM selama periode postmenopause. Pada wanita premenopause, akumulasi lemak pada ekstremitas bagian bawah sejauh ini diduga merupakan akibat dari sekresi estrogen. Selama masa menopause pola dari sekresi hormon berubah secara bertahap menyebabkan terjadi akumulasi lemak pada jaringan viseral abdomen dan sebagai akibatnya terjadi obesitas abdominal. Suatu penelitian longitudinal mengindikasikan bahwa penambahan berat badan merupakan perubahan utama pada para wanita postmenopause. Juga hubungan antara kadar FSH dan peningkatan ukuran lingkar pinggang meningkat dengan insidens obesitas abdominal. Suatu penelitian kohort pada berbagai kelompok etnis menunjukkan bahwa 13,7\% wanita terkena SM pada periode menopause dan semua komponen SM berhubungan secara signifikan pada para wanita setelah menopause. Selain itu, hasil penelitian tersebut menunjukkan bahwa kejadian SM pada para wanita postmenopause akibat dari menurunnya kadar estrogen dan adanya sekresi hormon testosteron, sehingga mengubah semua komponen SM menjadi signifikan. Menopause berhubungan dengan peningkatan dalam semua komponen dari SM antara lain timbul obesitas android, hipertensi, perubahan dari profil lipid yang tidak, baik, dan hiperinsulinemia. ${ }^{19}$

Pada subkelompok wanita dan pria, hasil penelitian ini mengindikasikan bahwa pada wanita terlihat peningkatan risiko mempunyai SM yang drastis pada kelompok umur mulai 50 tahun ke atas (peningkatan risiko SM 2,17 pada umur 50 - 59 tahun dan 3,58 kali pada umur 60 tahun dibanding kelompok usia $<30$ tahun). Pada pria di kelompok usia yang sama peningkatan tersebut tidak begitu signifikan (peningkatan risiko SM 1,56 kali pada umur 50 - 59 tahun dan 2,26 kali pada umur 60 dibanding kelompok usia $<30$ tahun). Etiologi dari SM belum dapat ditentukan secara jelas, tetapi terlihat bahwa SM berhubungan dengan obesitas abdominal. Oleh karena itu, teori perubahan metabolik selama masa menopause dan postmenopause dan peningkatan obesitas abdominal sebagai akibat dari penurunan estrogen merupakan satu dari hipotesis yang menjelaskan meningkatnya insiden dari SM selama periode tersebut. ${ }^{20}$ Hal tersebut juga sejalan dengan temuan pada penelitian ini yang menunjukkan pada subkelompok pria, perubahan OR untuk hubungan antara umur dan gender tidak tampak berubah drastis mulai dari kelompok umur $30-$ 39 sampai kelompok umur 50 - 59 tahun. Perubahan OR yang terjadi menunjukkan tidak terdapat kaitan umur dengan perubahan hormonal seperti pada wanita di usia yang sama. Dalam penelitian ini, terlihat risiko kejadian SM yang meningkat secara drastis pada kelompok wanita usia menopause dan postmenopause dibandingkan pada usia premenopause (peningkatan risiko SM 2,17 pada umur 50 - 59 tahun dan 3,58 kali pada umur 60 dibanding kelompok usia $<30$ tahun). Hal tersebut mengindikasikan bahwa temuan pada penelitian ini pada dasarnya sejalan dengan temuan penelitian sebelumnya. 21

\section{Risiko Sindrom Metabolik Berdasarkan Gender dan Status Pendidikan}

Hasil penelitian ini mengindikasikan pada strata pendidikan yang lebih rendah wanita lebih berisiko untuk mempunyai SM dibanding pria, sementara strata pendidikan yang lebih tinggi pria lebih berisiko untuk mempunyai SM dibanding wanita. Dibandingkan pada pria, kondisi tersebut dapat merefleksikan bahwa status sosialekonomi yang kurang baik pada wanita meningkatkan risiko SM. Diduga, pria dengan strata sosial ekonomi yang lebih rendah lebih besar kemungkinannya untuk terlibat dengan aktivitas yang membutuhkan lebih banyak tenaga fisik, meningkatkan penggunaan energi total, yang juga dapat memproteksi mereka dari berkembangnya SM, sementara para pria dengan pendidikan yang lebih tinggi, kurang menggunakan tenaga fisik dalam pekerjaannya yang kemudian menurunkan penggunaan energi total, sehingga meningkatkan risiko berkembangnya SM. Di antara kaum wanita, hasil penelitian ini mengindikasikan bahwa wanita berpendidikan tinggi berisiko untuk terkena SM lebih rendah dibanding yang berpendidikan menengah ke bawah. Di antara pria, hasil penelitian ini mengindikasikan tidak terdapat perbedaan risiko terkena SM berdasarkan strata pendidikan. Hasil penelitian ini tidak berbeda jauh dengan yang terjadi pada masyarakat Korea Selatan yang mengalami perubahan kondisi sosial ekonomi selama beberapa tahun terakhir ini. Ketidaksetaraan sosial ekonomi terhadap kejadian SM hanya ditemukan pada wanita, tetapi tidak pada pria. Terdapat ketidaksetaraan sosial ekonomi dalam SM pada para wanita Korea, tidak pada pria. Prevalens SM pada para wanita yang kurang berpendidikan lebih tinggi se- 
cara signifikan. ${ }^{15}$ Temuan tersebut didukung oleh temuan penelitian di Brazil yang menyatakan bahwa pada pria, baik pendidikan maupun pekerjaan tidak berhubungan dengan prevalens SM. ${ }^{14}$ Demikian juga pada penelitian ini, bila pendidikan dapat dianggap sebagai indikator sosial ekonomi, maka dalam penelitian ini sosial ekonomi berpengaruh terhadap kejadian SM pada wanita tetapi tidak pada pria. Wanita berpendidikan tinggi memiliki risiko SM yang lebih rendah dibanding wanita yang berpendidikan menengah ke bawah. Sementara itu, pada pria strata pendidikan tidak memengaruhi risiko kejadian SM. Hubungan terbalik antara tingkat pendidikan dengan SM lebih kuat pada wanita daripada pria. Kemungkinan terdapat kaitan dengan pengaruh pendidikan terhadap pilihan jenis makanan dan perilaku sehat yang berhubungan dengan SM. Karena pendidikan memfasilitasi pemahaman dan pengambilan keputusan untuk gaya hidup sehat dan karena para wanita pada umumnya lebih sadar kesehatan daripada pria, kombinasi dari kedua faktor tadi dapat menjelaskan proteksi yang lebih besar terhadap SM pada para wanita berpendidikan. ${ }^{22}$

\section{Risiko Sindrom Metabolik Berdasarkan Gender dan Status Perkawinan}

Hasil penelitian ini mengindikasikan pada strata janda dan kawin, wanita lebih berisiko SM dibanding pria dengan status perkawinan yang sama. Pada strata belum kawin tidak terdapat perbedaan risiko SM antara wanita dan pria. Di kalangan wanita, janda berisiko SM lebih tinggi daripada wanita yang belum menikah. Wanita menikah berisiko SM lebih kecil daripada yang belum menikah. Status perkawinan berhubungan dengan fase awal dari perkembangan penyakit kardiovaskuler, suatu hubungan yang mungkin terjadi sebagai bagian dari pengaruh kualitas perkawinan terhadap faktor metabolik. Para wanita yang menyatakan puas dalam perkawinan berisiko SM lebih rendah. Wanita yang puas dengan perkawinannya berisiko SM lebih rendah daripada para wanita yang tidak puas dengan perkawinan, bercerai, dan janda. Para wanita dengan perkawinan dengan kualitas yang tinggi berisiko lebih rendah untuk terkena SM. Wanita yang bercerai cenderung meningkatkan risiko dibandingkan wanita yang merasa puas dalam perkawinan. Hal ini mungkin disebabkan pajanan ketidakcocokan dalam perkawinan dan stres yang menyertai perceraian, termasuk penurunan sosek. Wanita janda juga berisiko SM lebih tinggi daripada wanita yang merasa puas dengan perkawinan, mungkin disebabkan efek kumulatif kedukaan dan stres yang berhubungan dengan kehilangan pasangan. ${ }^{23}$

Pada wanita, perkawinan dapat memberi perlindungan terhadap risiko yang berkaitan dengan isolasi sosial, memicu perilaku sehat dan menghentikan perilaku yang merusak kesehatan dan memengaruhi kesehatan secara tidak langsung dengan peningkatan sumber daya sosial ekonomi. Temuan tersebut sesuai dengan penelitian ini, wanita yang kawin berisiko SM lebih rendah daripada yang belum kawin. Kontras dengan hal tersebut, perkawinan yang tidak bahagia dapat menjadi stressor psikososial yang potensial bagi wanita, yang kemudian akan meningkatkan risiko kardiovaskuler. Di antara kaum pria, duda mempunyai risiko lebih tinggi untuk terkena SM daripada pria yang belum menikah. Pria menikah mempunyai risiko lebih kecil untuk terkena SM dibandingkan yang belum menikah. Pengakhiran suatu perkawinan dapat memperburuk kondisi insekuritas makanan. Pria yang bercerai lebih banyak menyatakan mempunyai keamanan yang rendah terhadap makanan daripada pria yang tidak pernah menikah. Dihipotesiskan bahwa individu yang bercerai dan berpisah dari pasangannya mempunyai prevalensi insekuritas makanan daripada yang mempunyai pasangan, tetapi keadaan tersebut tampak lebih nyata pada wanita daripada pria. ${ }^{24}$

Tanpa para istri, para pria yang bercerai mengalami sekuritas makanan yang sangat rendah karena tidak terdapat dukungan sosial untuk memediasi periode tekanan ekonomi. Pria bercerai menjadikan kelompok penting yang dapat dijadikan target untuk mendapat asistensi pemilihan makanan. Para pria menunjukkan pola yang berbeda dalam hubungan antara insekuritas makanan dengan berat badan. Seperi wanita, para pria dengan sekuritas makanan yang marginal mempunyai badan yang lebih berat daripada para pria dengan sekuritas makanan yang penuh. Sementara itu, para pria dengan sekuritas makanan yang rendah mempunyai berat badan yang lebih rendah dan lebih rendah kemungkinan untuk overweight. Di kalangan pria, sekuritas makanan yang marginal dapat berhubungan dengan kualitas diet yang memburuk atau makan yang tidak teratur dan berat badan yang lebih tinggi. Sekuritas makanan yang rendah mungkin dihubungkan dengan penurunan asupan makanan dan menyebabkan berat badan yang lebih rendah. ${ }^{24}$

Perceraian atau menduda berhubungan dengan peningkatan berat badan dan berat badan berhubungan dengan risiko SM. Obesitas merupakan salah satu komponen penting yang berkontribusi terhadap SM, dalam penelitian ini ditunjukkan bahwa pria duda lebih berisiko SM dibanding yang belum menikah. Penelitian di Polandia mengevaluasi hubungan antara status perkawinan dengan tekanan darah menyebutkan bahwa para pria yang tidak pernah menikah rata-rata mempunyai tekanan darah sistolik dan diastolik yang lebih tinggi dibanding para pria yang menikah. Pria yang tidak pernah menikah juga berisiko hipertensi lebih tinggi daripada para pria yang menikah. Perbedaan status perkawinan terhadap status psikologis stres berkepanjangan dan dukungan sosial yang rendah, asupan diet, dan aspek ekonomi dari hidup sendirian merupakan faktor yang menjelaskan paling tidak sebagai bagian dari perbedaan status perkawinan terhadap tekanan darah dan risiko 
hipertensi pada para pria. ${ }^{25}$ Temuan tersebut tampaknya sejalan dengan temuan pria yang kawin berisiko SM lebih rendah daripada yang tidak kawin. Pengaruh status tidak kawin terhadap hipertensi pada kaum pria mungkin dapat menjelaskan mengapa perkawinan merupakan faktor protektor dari SM pada pria.

\section{Kesimpulan}

Prevalensi SM dalam penelitian ini adalah 17,5\%. Prevalensi SM lebih tinggi pada wanita $(21,3 \%)$ daripada pria $(12,9 \%)$. Risiko SM berdasarkan gender tergantung pada status umur, pendidikan, dan perkawinan dari individu. Variasi kejadian SM berdasarkan pendapatan keluarga kecil (MOR 1,21) dan variasi kejadian SM berdasarkan propinsi juga kecil (MOR 1,18).

\section{Daftar Pustaka}

1. Reddy KS, Yusuf S. Emerging epidemic of cardiovasculer in developing countries, NCBI; 2000 [cited 2012 Aug 2]. Available from: www.pubmed.gov

2. Rustika. Pengembangan Model penyuluhan faktor risiko penyakit jantung lansia melalui peran keluarga [cited 2012 Sept 12]. Available from: http://digilib.litbang.depkes.go.id

3. Kelishadi R, Derakhshan R, Sabet B, Sarrafzadegan N, Kahbazi M, Sadri GH, et al. The metabolic syndrome in hypertensive and normotensive subject: The Isfahan Healthy Heart programme. Annals Academy of Medicine Singapore. 2005; 34: 243-9.

4. Regitz-Zagrosek V, Lehmkuhl E, Weickert MO. Gender difference in the metabolic syndrome and their role for cardiovascular disease. Clinical Research in Cardiology. 2006; 95 (3): 136-47.

5. Csaszar A, Kekes E, Abel T. Prevalence of metabolic syndrome estimated by International Diabetes Federation criteria in a Hungarian population. Blood Press. 2006; 15: 101-6.

6. Steyn K, Kazenellenbogen JM, Lombard CJ, Bourne LT. Urbanization and the risk for chronic diseases of lifestyle in the black population of the Cape Peninsula, South Africa. Journal of Cardiovascular Risk 1997; 4: 135-42.

7. O’Donnell S, Condell S, Begley C, Fitzgerald T. Prehospital care pathway delay: gender and myocardial infarction. Journal of Advanced Nursing. 2006; 53(3): 268-76.

8. Vaccarino V, Parsons L, Every NR, Barron HV, Krumholz HM. Sexbased differences in early mortality after myocardial infarction. National Registry of Myocardial Infarction 2 Participants. The New England Journal of Medicine. 1999; 341(4): 217-25.

9. Central Statistics Office Ireland. Central Statistics Office Website. 2007 [cited 2012 Jul 15]. Available from: http://www.cso.ie/. Accessed May 8, 2009

10. Denton M, Walters V. Gender differences in structural and behavioural determinants of health analysis of the social production of health. Social Science and Medicine 1999; 48 (9): 1221-35.

11. National Cholesterol Education Program (NCEP) Expert Panel on Detection, Evaluation, and Treatment of High Blood Cholesterol in Adults (Adult Treatment Panel III) 2002. Third Report of the National
Cholesterol Education Program (NCEP) Expert Panel on Detection, Evaluation, and Treatment of High Blood Cholesterol in Adults (Adult Treatment Panel III) final report. Circulation 106:3143-421. United States: NIH Publication; 2002.

12. The American Association of Clinical Endocrinologists (AACE), Einhorn D, Reaven GM, Cobin RH, Ford E, Ganda OP, Handelsman Y, et al. American College of Endocrinology position statement on the insulin resistance syndrome.Endocrine Practice. 2003; 9: 237-52.

13. Ford ES, Giles WH, Dietz WH. 2002. Prevalence of the metabolic syndrome among US adults: findings from the third National Health and Nutrition Examination Survey. Journal of the American Medical Association. 2002; 287: 356-9.

14. Marquezine GF, Oliveira CM, Pereira AC, Krieger JE, Mill JG. 2008. Metabolic syndrome determinants in an urban population from Brazil: social class and gender-specific interaction. Int J Cardiol 129: 259-65

15. Park MJ, Yun KE, Lee GE, Cho HJ, Park HS. A cross-sectional study of socioeconomic status and the metabolic syndrome in Korean adults. Annual Epidemiology. 2007; 17(4): 320-6.

16. Santos Ana, Ebrahim C Shah, Barros Henrique. Gender, socio-economic status and metabolic syndrome in middle-aged and old adults. BMC Public Health. 2008; 8: 62.

17. Pannier B, Thomas F, Eschwege E, Bean K, Benetos A, Leomach Y, et al. Cardiovascular risk markers associated with the metabolic syndrome in a large French population: The "SYMFONIE" study. Diabetes and Metabolism. 2006; 32: 467-74.

18. Park HS, Yun YS, Park JY, Kim YS, Choi JM. Obesity, abdominal obesity, and clustering of cardiovascular risk factors in South Korea. Asia Pacific Journal of Clinical Nutrition. 2003; 12: 411-8.

19. Carr MC. The emergence of the metabolic syndrome with menopause. The Journal of Clinical Endocrinology and Metabolism. 2003; 88: 2404-11.

20. Petri Nahas EA, Padoani NP, Nahas-Neto J, Orsatti FL, Tardivo AP, Dias R. Metabolic syndrome and its associated risk factors in Brazilian postmenopausal women. Climacteric. 2009; 12 (5): 1-8.

21. Ramin H, Masoumeh S, Mohammad T, Katayoun R, Noushin M, Nizal S. Metabolic syndrome in menopausal transition: Isfahan Healthy Heart Program, a population based study. Diabetology and Metabolic Syndrome. 2010; 2: 59.

22. Dallongeville J, Marecaux N, Cottel D, Bingham A, Amouyel P. Association between nutrition knowledge and nutritional intake in middle-aged among polish men from Northern France. Public Health Nutrition. 2001; 4: 27-33.

23. Scannell-Desch E. 2003. Women's adjustment to widowhood: theory, research, and interventions. Journal of Psychosocial Nursing and Mental Health Service. 2003; 41: 28-36.

24. Hobfall SE, Cameron RP, Chapman HA, Gallagher RW. Social support and social coping in couples. In: Pierce GR, Sarason BR, Sarason IG, editors. handbook of social support and the family. New York: Plenum Publishing; 1996. p. 123-42.

25. Lipowicz A, Lopuszanska M. Marrital differences in blood pressure and the risk of hypertension among polish men. European Journal of Epidemiology. 2002; 20 (5): 421-7. 